\title{
2008 MONITORING NETWORK PLAN
}

\section{Introduction}

Since 1979 the air monitoring program has been producing an annual NETWORK REVIEW. The purpose of this report was to document that the agency was actively evaluating monitoring requirements and using resources effectively. Federal regulatory changes in December of 2006 altered this old grant requirement to require an annual monitoring network plan supplemented every five years by an assessment of the air quality surveillance system. This is the Montana Department of Environmental Quality's (MTDEQ) second monitoring network plan.

The objective of this report is to accurately describe the monitoring sites in the agency network, and identify their monitoring objectives. It should also describe any deviations in physical characteristics or operation from regulatory requirements. The report will also describe changes we anticipate making to the network in the coming year. A summary of existing network sites is provided in Table 3 of this document. Table 4 identifies site locations. Site descriptions are ordered from lowest to highest AQS number which is also alphabetically by county.

\section{Monitoring Requirements}

The minimum number of monitors required by federal regulation is specified in the series of tables copied from the Code of Federal Regulations and presented below. There is no required minimum number of monitors for carbon monoxide and nitrogen oxides. The table in Figure 1 identifies the requirements for ozone monitors.

Table D-2 of Appendix D to Part 58- SLAMS Minimum $\mathrm{O}_{3}$ Monitoring Requirements

\begin{tabular}{|l|c|c|}
\hline \multicolumn{1}{|c|}{$\begin{array}{c}\text { MSA } \\
\text { population }\end{array}$} & $\begin{array}{c}\text { Most recent 3-year design value } \\
\text { concentrations } \mathbf{2 8 5} \% \text { of any } \\
\mathbf{O}_{\mathbf{3}} \mathbf{N A A Q \mathbf { A } ^ { 3 }}\end{array}$ & $\begin{array}{c}\text { Most recent 3-year design value } \\
\text { concentrations <85\% of any } \\
\mathbf{O}_{\mathbf{3}} \mathbf{N A A Q S} \mathbf{3 , 4}\end{array}$ \\
\hline$>10$ million & 4 & 2 \\
\hline $\begin{array}{l}\text { 4-10 million } \\
\text { 350,000-<4 } \\
\text { million }\end{array}$ & 3 & 1 \\
\hline $\begin{array}{l}50,000- \\
<350,000^{5}\end{array}$ & 2 & 1 \\
\hline
\end{tabular}

Figure 1 - Ozone Monitoring Requirements 
Montana has three MSAs with populations between 50,000 and 350,000 . The design value for Billings was determined during 2005-2007 to be $0.059 \mathrm{ppm}$ or $78.7 \%$ of the National Ambient Air Quality Standard (NAAQS). Measurements made in the Missoula MSA suggested a lower design value. No measurements of ozone have been made in Great Falls.

The minimum number of required $\mathrm{PM}_{10}$ sites is established by the table in Figure 2. None of Montana's three MSAs meets the requirement for medium concentration, so no $\mathrm{PM}_{10}$ sites are required.

\begin{tabular}{|c|c|c|c|}
\hline $\begin{array}{c}\text { Population } \\
\text { category }\end{array}$ & $\begin{array}{c}\text { High } \\
\text { concentration }^{2}\end{array}$ & $\begin{array}{c}\text { Medium } \\
\text { concentration }^{3}\end{array}$ & $\begin{array}{c}\text { Low } \\
\text { concentration }^{4,5}\end{array}$ \\
\hline$>1,000,000$ & $6-10$ & $4-8$ & $2-4$ \\
\hline $500,000-1,000,000$ & $4-8$ & $2-4$ & $1-2$ \\
\hline $250,000-500,000$ & $3-4$ & $1-2$ & $0-1$ \\
\hline $100,000-250,000$ & $1-2$ & $0-1$ & 0 \\
\hline \multicolumn{4}{|c|}{$\begin{array}{l}{ }^{1} \text { Selection of urban areas and actual numbers of stations per area within the ranges shown in this table will } \\
\text { be jointly determined by EPA and the State Agency. }\end{array}$} \\
\hline \multicolumn{4}{|c|}{$\begin{array}{l}{ }^{2} \text { High concentration areas are those for which ambient PM10 data show ambient concentrations exceeding } \\
\text { the PM } \mathrm{PM}_{10} \mathrm{NAAQS} \text { by } 20 \text { percent or more. }\end{array}$} \\
\hline \multicolumn{4}{|c|}{$\begin{array}{l}{ }^{3} \text { Medium concentration areas are those for which ambient PM10 data show ambient concentrations } \\
\text { exceeding } 80 \text { percent of the } \mathrm{PM}_{10} \text { NAAQS. }\end{array}$} \\
\hline \multicolumn{4}{|c|}{$\begin{array}{l}{ }^{4} \text { Low concentration areas are those for which ambient PM10 data show ambient concentrations less than } 80 \\
\text { percent of the PM }{ }_{10} \text { NAAQS. }\end{array}$} \\
\hline
\end{tabular}

Figure $2-\mathrm{PM}_{10}$ Monitoring Requirements

The table in Figure 3 below indicates that any of Montana's three MSA's with a $\mathrm{PM}_{2.5}$ design value exceeding $85 \%$ of the NAAQS requires a $\mathrm{PM}_{2.5}$ monitoring site. Missoula County meets this requirement and has a $\mathrm{PM}_{2.5}$ monitoring site at the Health Department.

In summary, the number of air quality monitors required by regulation in an area is a function of population density and air quality. No population area in Montana has enough people to require more than one monitor for any pollutant where air quality is bad and to require any monitoring where air quality is good. MTDEQ has monitors in place where there are known air quality issues and continues to investigate suspect areas. 
Table D-5 of Appendix D to Part 58. $\mathrm{PM}_{2.5}$ Minimum Monitoring Requirements

\begin{tabular}{|l|c|c|}
\hline $\begin{array}{c}\text { MSA } \\
\text { population }\end{array}$ & $\begin{array}{c}\text { Most recent 3-year design value } \\
\mathbf{2 8 5 \%} \text { of any } \mathbf{P M}_{\mathbf{2 . 5}} \mathbf{N A A Q S}^{\mathbf{3}}\end{array}$ & $\begin{array}{c}\text { Most recent 3-year design value } \\
<\mathbf{8 5 \%} \text { of any } \mathbf{P M}_{\mathbf{2 . 5}} \mathbf{N A A Q S} \mathbf{A S}^{\mathbf{3 , 4}}\end{array}$ \\
\hline$>1,000,000$ & 3 & 2 \\
\hline $\begin{array}{l}500,000- \\
1,000,000\end{array}$ & 2 & 1 \\
\hline $\begin{array}{l}50,000- \\
<500,000^{5}\end{array}$ & 1 & 0 \\
\hline
\end{tabular}

${ }^{1}$ Minimum monitoring requirements apply to the Metropolitan statistical area (MSA).

${ }^{2}$ Population based on latest available census figures.

${ }^{3}$ The $\mathrm{PM}_{2.5}$ National Ambient Air Quality Standards (NAAQS) levels and forms are defined in 40 CFR part 50.

${ }^{4}$ These minimum monitoring requirements apply in the absence of a design value.

${ }^{5}$ Metropolitan statistical areas (MSA) must contain an urbanized area of 50,000 or more population.

Figure $3-\mathrm{PM}_{2.5}$ Monitoring Requirements

MTDEQ's air monitoring sites meet all of the EPA's siting requirements with the few exceptions described below, and they are all operated to conform with EPA requirements for quality control and quality assurance for SLAMS sites.

\section{Monitoring Sites}

\section{0-013-0001 Great Falls-Overlook Park}

This site was established in 2001 to monitor carbon monoxide continuously. It is microscale representative, and its monitoring objective is to track compliance with the NAAQS for the "Limited Maintenance Plan" in the $10^{\text {th }}$ Avenue $\mathrm{CO}$ nonattainment corridor. A continuous $\mathrm{PM}_{2.5}$ monitor was added to the site during the spring of 2008 to provide near, real-time particulate data for use on the "todaysair" website.

\section{0-013-1026 Great Falls-High School}

This site has been monitoring $\mathrm{PM}_{2.5}$ since January 2000. The neighborhood scale site is near the center of the city, and was established to monitor population exposure to area $\mathrm{PM}_{2.5}$ emissions. The monitor is in the corner of a large football field and about 5 meters from each of two roadways. While this is undesirably close to the roads, one dead-ends at the end of the block, and the other has very little traffic. 
30-029-0007 Columbia Falls-Ball Park

This collocated $\mathrm{PM}_{10}$ site began operating in 2006 and exists to demonstrate continued compliance with the NAAQS in the Columbia Falls PM $_{10}$ nonattainment area. $\mathrm{PM}_{2.5}$ monitoring was added in 2008. The site is neighborhood scale and located in the corner of a park between an industrial park to the North and a residential neighborhood to the South. A tree partially obstructs about 90 degrees to the East, and the monitors are closer than desirable to the adjacent roadways which are paved and have very low traffic volumes.

\section{0-029-0009 Whitefish-Dead End}

This particulate site monitors both $\mathrm{PM}_{10}$ and $\mathrm{PM}_{2.5}$. It is located at the end of $10^{\text {th }}$ Street near the point where US 93 crosses the Whitefish River. The site is representative at the neighborhood scale and was installed to provide continuing monitoring for the $\mathrm{PM}_{10}$ nonattainment area designated in 1993, and to assess population exposure to fine particulate. It also provides continuous particulate data for the local burning control program.

\section{0-029-0010 Kalispell-Moose's Saloon}

This microscale carbon monoxide site is on the south side of Idaho Ave. near the intersection of Idaho \& Main in downtown Kalispell. Exceedances of the CO NAAQS were measured across the street from this site in 1996, and subsequent studies have shown this to be the highest carbon monoxide area in Kalispell. The site was established in 2003 to monitor continuing compliance with the NAAQS.

\section{0-029-0047 Kalispell-Flathead Electric}

This particulate site was installed in 1999 to consolidate particulate monitoring in Kalispell. The site is neighborhood scale and provides population exposure information for both $\mathrm{PM}_{10}$ and $\mathrm{PM}_{2.5}$. It also provides continuous particulate data for the county's burning control program, and demonstrates continuing compliance with the NAAQS in the Kalispell PM $_{10}$ nonattainment area designated in 1990.

\section{0-031-0006 Bozeman-Wastewater Treatment Plant}

This $\mathrm{PM}_{2.5}$ site is located at the north-west corner of Bozeman adjacent to the wastewater treatment plant. It is neighborhood scale, and it was positioned to measure down-slope flow from Bozeman toward Belgrade. While the site does represent some population, it's principle function is to provide information on fine particulate dynamics in the Gallatin Valley. Continuous $\mathrm{PM}_{2.5}$ monitoring was added in early 2008 to provide near, real-time particulate data for use on the "todaysair" website.

30-031-0008 Belgrade-ConAgra 
This $\mathrm{PM}_{2.5}$ site is located close to the center of the community. It is neighborhood scale and provides exposure information for the population. This site consistently measures the highest values in the Gallatin Valley. Land use changes may force us from this site in the near future.

\section{0-031-0013 West Yellowstone-Park Entrance}

This site monitors carbon monoxide and $\mathrm{PM}_{2.5}$. It was established in 1998 to measure $\mathrm{CO}$ at the park entrance, and it followed the park entrance about $1 / 4$ mile into the park during the spring of 2008. It is microscale in its representation. Continuous $\mathrm{PM}_{2.5}$ monitoring was added in 2003. The site is very close to the entrance roadway and it is surrounded by tall trees. Air flow at monitoring height is up and down the roadway. Results are relevant to only the immediate locale. This site is funded by the National Park Service, but operated to EPA requirements.

\section{0-031-0016 West Yellowstone-City Center}

This site was established in 2007 to monitor community wide exposure to carbon monoxide and fine particulate. It is in the center of town and it is neighborhood scale in its representation. Like the Park Entrance site, this site is funded by the National Park Service, but operated like an EPA SLAMS site.

\section{0-049-0018 Helena-Lincoln School}

This neighborhood scale site has been monitoring population exposure to particulate since 1989 . It is currently measuring $\mathrm{PM}_{2.5}$ both continuously and at three day intervals.

\section{0-049-0026 Helena-Rossiter Pump House}

This neighborhood scale site is in the middle of an elementary school play field at the bottom of the Helena Valley. It exists to monitor population exposure to fine particulate and to track the impact of continuing development in the valley. The site has a long history of measuring $\mathrm{PM}_{10}$, but it was switched to measuring $\mathrm{PM}_{2.5}$ in January of 2007.

\section{0-053-0018 Libby-Courthouse Annex}

This neighborhood scale site is on the roof of the Courthouse Annex in the center of Libby, MT. It has been in operation since 1987. It is currently measuring particulate for population exposure and compliance with the NAAQS in the $\mathrm{PM}_{10}$ and $\mathrm{PM}_{2.5}$ nonattainment areas.

30-063-0005 Missoula-Malfunction Junction

This microscale site exists to track continuing compliance with the carbon monoxide NAAQS in the Missoula CO nonattainment area. It operates only during the winter quarters when Missoula is subject to inversions. 


\section{0-063-0021 Seeley Lake}

This neighborhood scale site was installed along the main corridor (US 83) through town to monitor population exposure to $\mathrm{PM}_{10}$ and $\mathrm{PM}_{2.5}$. Data collected since 2004 is inconclusive, but indicates that $\mathrm{PM}_{2.5}$ is occasionally high.

30-063-0024 Missoula-Boyd Park

This neighborhood scale site has collected particulate data since 1981. It currently monitors $\mathrm{PM}_{10}$ continuously to demonstrate continuing compliance with the NAAQS in the Missoula $\mathrm{PM}_{10}$ nonattainment area.

\section{0-063-0031 Missoula-Health Department}

This neighborhood scale site is located on the roof of the city-county health department. It has monitored particulate since 1985. The site is currently a Speciation Trends $\mathrm{PM}_{2.5}$ site. It also samples $\mathrm{PM}_{2.5}$ and $\mathrm{PM}_{10}$. The site's objective is to monitor population exposure to particulate and compliance with the NAAQS.

\section{0-081-0007 Hamilton-PS\#46}

This neighborhood scale site is located in parking spot number 46 in the sheriff's lot at the corner of Madison and $3^{\text {rd }}$ Street South. It has both continuous and FRM PM 2.5 monitors. The site was established in 2005 less than a block away from our former site on the Courthouse roof to monitor population exposure and compliance with the NAAQS. The move was made to accommodate continuous monitoring required for near-real-time reporting of smoke during the summer wildfire season. The site is on a paved lot within 5 meters of a gravel alley and Madison St. which is paved. The alley sees virtually no use, and Madison street is low volume.

\section{0-089-0007 Thompson Falls-High School}

This site is located on the East side of Thompson Falls at the High School. It is neighborhood scale in its representation and it was established in 1999 to monitor population exposure to $\mathrm{PM}_{10}$ and $\mathrm{PM}_{2.5}$ and compliance with the NAAQS. Thompson Falls was designated nonattainment for $\mathrm{PM}_{10}$ in December of 1993.

\section{0-093-0005 Butte-Greeley School}

This neighborhood scale site is located at an elementary school in a residential neighborhood on the north side of Butte near the current mining activity. The site monitors population exposure to particulate. Continuous PM10 monitoring provides response capability for the burning control program and monitors compliance with the NAAQS. PM2.5 compliance is measured with an FRM sampler. Butte was designated nonattainment for $\mathrm{PM}_{10}$ in 1990.

\section{0-093-0009 Butte-Front Street}

This site is in the parking lot of the Butte-Silverbow Health Department office. It was established in 2007 and it is neighborhood scale representative. It provides continuous $\mathrm{PM}_{2.5}$ data for assessing population exposure. 
30-111-0066 Billings-Coburn Rd.

This neighborhood scale site is located on high ground south of the Conoco and Exxon refineries. It is a major receptor for $\mathrm{SO}_{2}$ and exists to monitor compliance with the federal and state $\mathrm{SO}_{2}$ standards.

\section{0-111-0085 Billings-St. Luke's}

This micro scale carbon monoxide site is in downtown Billings at the corner of $2^{\text {nd }}$ Ave. North and North $32^{\text {nd }}$ Street. This site was installed to demonstrate Billings' continuing compliance with the CO NAAQS. Continuous $\mathrm{PM}_{2.5}$ monitoring was added in the spring of 2008 to provide near, real-time particulate data for the "todaysair" website.

\section{0-111-0086 Shepherd-Bus Barn}

This neighborhood scale site was located to receive maximum ozone impact from Billings. It is about ten miles north-east of Billings in the Yellowstone River valley. It began monitoring nitrogen oxides and ozone in June of 2005. The values measured were too low to require continued monitoring, so the site was closed in January 2008.

\section{0-111-1065 Billings-Lockwood Park}

This neighborhood scale particulate site is located at Lockwood Park on Old Hardin Road at the east end of Billings. It has monitored population exposure to $\mathrm{PM}_{2.5}$ since 1999.

All of these sites meet the requirements of 40 CFR part 58 Appendices $A$, $\mathrm{C}$, and $\mathrm{D}$. Three sites do not meet all of the siting requirements of Appendix $\mathrm{E}$. Sites 30-013-1026 and 30-081-0007 are less than 15 meters from roadways and site 30-063-0021 has partially obstructed air flow.

$\mathrm{PM}_{2.5}$ monitoring sites, representative of a smaller than neighborhood spatial scale, are not eligible for comparison to the annual $\mathrm{PM}_{2.5}$ NAAQS. Data from such sites is eligible for comparison to only the 24 hour $\mathrm{PM}_{2.5}$ NAAQS. The only MTDEQ $\mathrm{PM}_{2.5}$ site of this nature is the microscale site at the west entrance to Yellowstone National Park (30-031-0013). All other $\mathrm{PM}_{2.5}$ monitors can be compared to the Annual NAAQS.

If circumstances should make it necessary or desirable to relocate a violating $\mathrm{PM}_{2.5}$ monitor, the change would be discussed among an existing local program, Air Quality Permitting, the Air Planning Section and the Air Monitoring Section. The Air Monitoring Section would seek public comment through the annual Monitoring Network Plan and would seek EPA approval for the change. No such change would ever be made without demonstrating that a replacement site produced comparably high values unless circumstances precluded such a comparison. Montana does not have any community monitoring zones or 
anticipate creating one, so the impact of relocating a site on such zones is not relevant.

\section{Proposed Changes}

In May and June of 2008 MTDEQ reorganized continuous $\mathrm{PM}_{2.5}$ monitors to add continuous monitoring to Great Falls, Bozeman, and Billings while retaining this capability where it already existed. The objective was to convert all data appearing on the agency's "todaysair" website to $\mathrm{PM}_{2.5}$ and eliminate the confusion associated with presenting a mixture of $\mathrm{PM}_{10}$ and $\mathrm{PM}_{2.5}$ data. The todaysair web site was created to present near, real-time particulate information primarily during the summer wild fire season, and from its inception has presented all of the continuous particulate data available whether it was $\mathrm{PM}_{10}$ or $\mathrm{PM}_{2.5}$. While this is adequate for informing the public of the risks of the very high particulate concentrations associated with summer fires, it has created confusion during other more normal seasons and circumstances. It was also decided that these three most populous cities in Montana should be added to the website because, even though they don't have problems with attainment of the National Ambient Air Quality Standards, they can be heavily impacted by smoke during the summer wild fire season.

As part of the above endeavor, we propose to add continuous PM2.5 monitoring to the Boyd Park site in Missoula. We hope to accomplish this during July, and complete the transition from presenting mixed particulate data on the near, real-time website to presenting only PM2.5 data.

MTDEQ monitors carbon monoxide in four communities even though the measured values are low and either stable or declining (see Table 1). While

\begin{tabular}{|c|c|c|c|c|c|c|c|c|c|c|c|c|c|c|c|c|}
\hline \multirow[t]{3}{*}{ Year } & \multicolumn{4}{|c|}{ Great Falls } & \multicolumn{4}{|c|}{ Kalispell } & \multicolumn{4}{|c|}{ Missoula } & \multicolumn{4}{|c|}{ Billings } \\
\hline & \multicolumn{2}{|c|}{ Max Hour } & \multicolumn{2}{|c|}{$\operatorname{Max} 8 \mathrm{Hr}$} & \multicolumn{2}{|c|}{ Max Hour } & \multicolumn{2}{|c|}{$\operatorname{Max} 8 \mathrm{Hr}$} & \multicolumn{2}{|c|}{ Max Hour } & \multicolumn{2}{|c|}{$\operatorname{Max} 8 \mathrm{Hr}$} & \multicolumn{2}{|c|}{ Max Hour } & \multicolumn{2}{|c|}{$\operatorname{Max} 8 \mathrm{Hr}$} \\
\hline & $1 \mathrm{st}$ & 2nd & $1 \mathrm{st}$ & 2nd & $1 \mathrm{st}$ & 2nd & $1 \mathrm{st}$ & 2nd & $1 \mathrm{st}$ & 2nd & $1 \mathrm{st}$ & 2nd & $1 \mathrm{st}$ & 2nd & 1st & 2nd \\
\hline 1995 & 13.9 & 13.7 & 7.9 & 6.2 & 9.7 & 9.2 & 7.6 & 6.5 & 8.9 & 8.5 & 7.8 & 6.6 & 16.5 & 13.6 & 7.1 & 6.6 \\
\hline 1996 & 21.9 & 19.1 & 8.5 & 5.4 & 17.4 & 13.4 & 11.4 & 11.1 & 6.7 & 6.7 & 5.8 & 5.6 & 14.8 & 11.1 & 6 & 4.7 \\
\hline 1997 & 11.1 & 10 & 7.4 & 6.4 & 6.2 & 6.1 & 4.9 & 4.9 & 8.1 & 8.1 & 6.3 & 4.9 & 9.2 & 8.6 & 5.2 & 4.9 \\
\hline 1998 & 10.3 & 8.7 & 5.3 & 4.5 & 6.6 & 6.5 & 5.3 & 5 & 5.7 & 5.6 & 4.7 & 4.7 & 13.3 & 12.8 & 5.9 & 4.8 \\
\hline 1999 & 7.8 & 7.1 & 3.6 & 3.5 & 9.1 & 7.9 & 5.3 & 4.8 & 6 & 5.8 & 4.9 & 4.4 & 10 & 6.7 & 3.4 & 3.4 \\
\hline 2000 & 6.7 & 6.5 & 4.6 & 3.6 & 8 & 7 & 4.3 & 4.3 & 5.4 & 4.9 & 3.9 & 3.3 & 10.6 & 8.2 & 5.1 & 4.9 \\
\hline 2001 & 7.4 & 7.2 & 4.6 & 3.6 & 6 & 5.7 & 3.8 & 3.7 & 7 & 6.6 & 5.5 & 3.9 & 9 & 8.6 & 5.6 & 5.2 \\
\hline 2002 & 7.3 & 5.5 & 3 & 2.8 & 5.4 & 5.3 & 3.4 & 3.3 & 5.7 & 5.2 & 4.6 & 3.6 & 8.9 & 8.5 & 5 & 4.9 \\
\hline 2003 & 4.8 & 4.6 & 2.9 & 2.7 & 5 & 4.8 & 3.2 & 3 & 4.5 & 4.4 & 4 & 3.6 & 7.8 & 7.5 & 5.7 & 4.4 \\
\hline 2004 & 7.2 & 5.7 & 3.2 & 2.4 & 5 & 4.7 & 3.2 & 2.9 & 3.9 & 3.6 & 3.2 & 2.9 & 8.1 & 6.8 & 4.4 & 3.7 \\
\hline 2005 & 4 & 3.7 & 2 & 2 & 5.9 & 5.5 & 3.6 & 3.3 & 4.3 & 4.3 & 4.1 & 3.6 & 13.4 & 5.6 & 3.7 & 3.5 \\
\hline 2006 & 3 & 2.8 & 2.2 & 1.7 & 5.3 & 4.6 & 3 & 2.6 & 3.1 & 3 & 2.5 & 2.4 & 5.9 & 4.9 & 2.7 & 2 \\
\hline
\end{tabular}

Table 1 - Carbon Monoxide 
these communities had problems with carbon monoxide in the past, those days have clearly passed. Unfortunately, regulations developed back then to control $\mathrm{CO}$ emissions also required monitoring to track progress, and no provision was made to ever discontinue monitoring. The agency is currently exploring its options for discontinuing this required but unnecessary carbon monoxide monitoring.

At the end of June 2008 we propose to discontinue $\mathrm{PM}_{2.5}$ speciation sampling in Libby. Speciation of fine particulate in Libby began over six years ago when it began to appear likely that Libby was not in compliance with the $\mathrm{PM}_{2.5}$ standard. Speciation results were useful in characterizing the problem and in documenting the effect of the wood stove change-out, but that need has passed, and it is time to make this resource available elsewhere. We propose to begin $\mathrm{PM}_{2.5}$ speciation sampling at Butte-Greeley School on 9/01/08. The metals content of fine particulate is a matter of considerable interest in Butte.

We also propose to discontinue $\mathrm{PM}_{10}$ monitoring at the Missoula-Health Department site at the end of 2008. A comparison of data from the two sites in Missoula (Health Department and Boyd Park) shows no real difference between them for either maximum daily values or annual averages. See Table 2. To continue monitoring $\mathrm{PM}_{10}$ at both sites would be a waste of resources.

\begin{tabular}{|c|c|c|c|c|c|c|c|c|c|c|}
\hline & \multicolumn{4}{|c|}{ Boyd Park } & \multicolumn{5}{c|}{ Health Department } \\
\cline { 2 - 12 } Year & $\begin{array}{c}\text { 1st } \\
\text { Max }\end{array}$ & $\begin{array}{c}\text { 2nd } \\
\text { Max }\end{array}$ & $\begin{array}{c}\text { 3rd } \\
\text { Max }\end{array}$ & $\begin{array}{c}\text { 4th } \\
\text { Max }\end{array}$ & Mean & $\begin{array}{c}\text { 1st } \\
\text { Max }\end{array}$ & $\begin{array}{c}\text { 2nd } \\
\text { Max }\end{array}$ & $\begin{array}{c}\text { 3rd } \\
\text { Max }\end{array}$ & $\begin{array}{c}\text { 4th } \\
\text { Max }\end{array}$ & Mean \\
\hline 1995 & 83 & 81 & 77 & 69 & 24 & 67 & 53 & 49 & 46 & 26 \\
\hline 1996 & 113 & 112 & 102 & 97 & 24 & 71 & 51 & 51 & 50 & 28 \\
\hline 1997 & 88 & 88 & 70 & 65 & 21 & 78 & 55 & 49 & 48 & 26 \\
\hline 1998 & 126 & 73 & 70 & 69 & 20 & 72 & 51 & 50 & 43 & 23 \\
\hline 1999 & 60 & 55 & 42 & 42 & 17 & 46 & 43 & 42 & 38 & 20 \\
\hline 2000 & 164 & 137 & 120 & 102 & 21 & 193 & 115 & 69 & 69 & 28 \\
\hline 2001 & 91 & 72 & 69 & 68 & 19 & 63 & 55 & 47 & 45 & 21 \\
\hline 2002 & 46 & 44 & 41 & 40 & 16 & 43 & 42 & 39 & 38 & 20 \\
\hline 2003 & 109 & 100 & 54 & 54 & 24 & 134 & 116 & 110 & 107 & 21 \\
\hline 2004 & 86 & 54 & 52 & 51 & 22 & 49 & 47 & 46 & 45 & 19 \\
\hline 2005 & 85 & 58 & 54 & 51 & 22 & 57 & 52 & 52 & 50 & 18 \\
\hline 2006 & 85 & 80 & 74 & 70 & 24 & 51 & 46 & 42 & 41 & 23 \\
\hline 2007 & 138 & 124 & 87 & 87 & 24 & 129 & 54 & 52 & 46 & 24 \\
\hline
\end{tabular}

Table 2 - Missoula $\mathrm{PM}_{10}$

The above changes may occur. They reflect our current intensions. No changes will actually occur without additional discussions with EPA Region 8 and approval of a formal Network Modification Request. 
Table 3

Existing Montana Ambient Air Monitoring Network

\begin{tabular}{|c|c|c|c|c|c|c|c|}
\hline AQS Number & $\begin{array}{c}\text { Site } \\
\text { City-Name } \\
\end{array}$ & Parameter & Method & Frequency & Type & $\begin{array}{l}\text { Spatial } \\
\text { Scale }\end{array}$ & $\begin{array}{l}\text { Location } \\
\text { Type }^{*}\end{array}$ \\
\hline 30-013-0001 & Great Falls-Overlook Park & $\begin{array}{l}42101-\mathrm{CO} \\
88502-\mathrm{PM}_{2.5}\end{array}$ & $\begin{array}{l}093^{1} \\
731^{5}\end{array}$ & $\begin{array}{l}\text { Continuous } \\
\text { Continuous }\end{array}$ & $\begin{array}{l}\text { SLAMS } \\
\text { SPM }\end{array}$ & $\begin{array}{l}\text { Micro. } \\
\text { Middle }\end{array}$ & $\begin{array}{l}\mathrm{H}, \mathrm{P}, \mathrm{S} \\
\mathrm{H}, \mathrm{P}\end{array}$ \\
\hline 30-013-1026 & Great Falls-High School & $88101-\mathrm{PM}_{2.5}$ & $142^{2}$ & 1 in 3 & SLAMS & Neigh. & $\mathrm{H}, \mathrm{P}$ \\
\hline 30-029-0007 & Columbia Falls-Ball Park & $\begin{array}{l}81102-\mathrm{PM}_{10} \\
85101-\mathrm{PM}_{10} \\
88101-\mathrm{PM}_{2.5}\end{array}$ & $\begin{array}{l}125^{3} \\
142^{2}\end{array}$ & $\begin{array}{l}1 \text { in } 6 \\
\text { (collocated) } \\
1 \text { in } 3\end{array}$ & $\begin{array}{l}\text { SLAMS } \\
\text { SLAMS }\end{array}$ & $\begin{array}{l}\text { Neigh } \\
\text { Neigh }\end{array}$ & $\begin{array}{l}H, P, S \\
H, P\end{array}$ \\
\hline 30-029-0009 & Whitefish-Dead End & $\begin{array}{l}88502-\mathrm{PM}_{2.5} \\
88101-\mathrm{PM}_{2.5} \\
81102-\mathrm{PM}_{10} \\
85101-\mathrm{PM}_{10}\end{array}$ & $\begin{array}{l}731^{5} \\
142^{2} \\
125^{3} \\
125^{3}\end{array}$ & $\begin{array}{l}\text { Continuous } \\
1 \text { in } 3 \\
1 \text { in } 6 \\
1 \text { in } 6\end{array}$ & $\begin{array}{l}\text { SPM } \\
\text { SLAMS } \\
\text { SLAMS } \\
\text { SLAMS }\end{array}$ & $\begin{array}{l}\text { Neigh. } \\
\text { Neigh. } \\
\text { Neigh. } \\
\text { Neigh. }\end{array}$ & $\begin{array}{l}\mathrm{H}, \mathrm{P} \\
\mathrm{H}, \mathrm{P} \\
\mathrm{H}, \mathrm{P} \\
\mathrm{H}, \mathrm{P}\end{array}$ \\
\hline $30-029-0010$ & Kalispell-Moose's & 42101-CO & $093^{1}$ & Continuous & SLAMS & Micro. & $\mathrm{H}, \mathrm{P}, \mathrm{S}$ \\
\hline 30-029-0047 & Kalispell-Flathead Electric & $\begin{array}{l}88502-\mathrm{PM}_{2.5} \\
88101-\mathrm{PM}_{2.5} \\
81102-\mathrm{PM}_{10} \\
85101-\mathrm{PM}_{10}\end{array}$ & $\begin{array}{l}731^{5} \\
142^{2} \\
122^{4} \\
122\end{array}$ & $\begin{array}{l}\text { Continuous } \\
1 \text { in } 3 \\
1 \text { in } 6 \\
1 \text { in } 6\end{array}$ & $\begin{array}{l}\text { SPM } \\
\text { SLAMS } \\
\text { SLAMS } \\
\text { SLAMS }\end{array}$ & $\begin{array}{l}\text { Neigh. } \\
\text { Neigh. } \\
\text { Neigh. } \\
\text { Neigh. }\end{array}$ & $\begin{array}{l}\mathrm{H}, \mathrm{P} \\
\mathrm{H}, \mathrm{P} \\
\mathrm{H}, \mathrm{P} \\
\mathrm{H}, \mathrm{P}\end{array}$ \\
\hline 30-031-0006 & $\begin{array}{c}\text { Bozeman-Waste Water } \\
\text { Treatment Plant }\end{array}$ & $\begin{array}{l}88101-\mathrm{PM}_{2.5} \\
88502-\mathrm{PM}_{2.5}\end{array}$ & $\begin{array}{l}142^{2} \\
731^{5}\end{array}$ & $\begin{array}{l}1 \text { in } 3 \\
\text { Continuous }\end{array}$ & $\begin{array}{l}\text { SLAMS } \\
\text { SPM }\end{array}$ & $\begin{array}{l}\text { Neigh. } \\
\text { Neigh. }\end{array}$ & $\begin{array}{l}\mathrm{H}, \mathrm{P} \\
\mathrm{P}\end{array}$ \\
\hline $30-031-0008$ & Belgrade-ConAgra & $88101-\mathrm{PM}_{2.5}$ & $142^{2}$ & 1 in 3 & SLAMS & Neigh. & $\mathrm{H}, \mathrm{P}$ \\
\hline
\end{tabular}


Table 3 (Continued)

Existing Montana Ambient Air Monitoring Network

\begin{tabular}{|c|c|c|c|c|c|c|c|}
\hline AQS Number & $\begin{array}{c}\text { Site } \\
\text { City-Name } \\
\end{array}$ & Parameter & Method & Frequency & Type & $\begin{array}{l}\text { Spatial } \\
\text { Scale }\end{array}$ & $\begin{array}{c}\begin{array}{l}\text { Location } \\
\text { Type }^{*}\end{array} \\
\end{array}$ \\
\hline \multicolumn{8}{|c|}{${ }^{\star} \mathrm{H}=$ high concentration, $\mathrm{P}=$ population exposure, $\mathrm{S}=$ source impact, $\mathrm{B}=$ background } \\
\hline 30-031-0013 & $\begin{array}{l}\text { West Yellowstone-Park } \\
\text { Entrance }\end{array}$ & $\begin{array}{l}42101-\mathrm{CO} \\
88502-\mathrm{PM}_{2.5}\end{array}$ & $\begin{array}{l}093^{1} \\
731^{5}\end{array}$ & $\begin{array}{l}\text { Continuous } \\
\text { Continuous }\end{array}$ & $\begin{array}{l}\text { SPM } \\
\text { SPM }\end{array}$ & $\begin{array}{l}\text { Micro } \\
\text { Micro }\end{array}$ & $\begin{array}{l}S \\
S\end{array}$ \\
\hline 30-031-0016 & West Yellowstone-City Center & $\begin{array}{l}42101-\mathrm{CO} \\
88101-\mathrm{PM}_{2.5}\end{array}$ & $\begin{array}{l}093^{1} \\
170^{8}\end{array}$ & $\begin{array}{l}\text { Continuous } \\
\text { Continuous }\end{array}$ & $\begin{array}{l}\text { SLAMS } \\
\text { SLAMS }\end{array}$ & $\begin{array}{l}\text { Micro } \\
\text { Neigh. }\end{array}$ & $\begin{array}{l}\mathrm{H}, \mathrm{P} \\
\mathrm{H}, \mathrm{P}\end{array}$ \\
\hline 30-049-0018 & Helena-Lincoln School & $\begin{array}{l}88101-\mathrm{PM}_{2.5} \\
88502-\mathrm{PM}_{2.5}\end{array}$ & $\begin{array}{l}142^{2} \\
170^{8}\end{array}$ & $\begin{array}{l}1 \text { in } 3 \\
\text { Continuous }\end{array}$ & $\begin{array}{l}\text { SLAMS } \\
\text { SPM }\end{array}$ & $\begin{array}{l}\text { Neigh. } \\
\text { Neigh. }\end{array}$ & $\begin{array}{l}\mathrm{H}, \mathrm{P} \\
\mathrm{H}, \mathrm{P}\end{array}$ \\
\hline 30-049-0026 & Helena-Rossiter Pump House & $88101-\mathrm{PM}_{2.5}$ & $142^{2}$ & 1 in 6 & SLAMS & Neigh. & $P$ \\
\hline \multirow[t]{3}{*}{ 30-053-0018 } & Libby-Courthouse Annex & $\begin{array}{l}81102-\mathrm{PM}_{10} \\
85101-\mathrm{PM}_{10} \\
\mathrm{PM}_{2.5} \text { Speciation }\end{array}$ & $\begin{array}{l}122^{4} \\
122 \\
810^{6}\end{array}$ & $\begin{array}{l}\text { Continuous } \\
\text { Continuous } \\
1 \text { in } 6\end{array}$ & $\begin{array}{l}\text { SLAMS } \\
\text { SLAMS } \\
\text { Supplmtl } \\
\text { Speciation }\end{array}$ & $\begin{array}{l}\text { Neigh. } \\
\text { Neigh. } \\
\text { Neigh. }\end{array}$ & $\begin{array}{l}\mathrm{H}, \mathrm{P} \\
\mathrm{H}, \mathrm{P} \\
\mathrm{H}, \mathrm{P}\end{array}$ \\
\hline & & & $142^{2}$ & 1 in 3 & SLAMS & Neigh. & $\mathrm{H}, \mathrm{P}$ \\
\hline & & $88101-\mathrm{PM}_{2.5}$ & $731^{5}$ & Continuous & SPM & Neigh. & $\mathrm{H}, \mathrm{P}$ \\
\hline 30-063-0005 & Missoula-Malfunction Junction & $42101-\mathrm{CO}$ & $093^{1}$ & $\begin{array}{l}\text { Continuous } \\
1^{\text {st }} \& 4^{\text {th }} \\
\text { quarters }\end{array}$ & SLAMS & Micro & $\mathrm{H}, \mathrm{P}, \mathrm{S}$ \\
\hline 30-063-0021 & Seeley Lake & $\begin{array}{l}81102-\mathrm{PM}_{10} \\
85101-\mathrm{PM}_{10} \\
88101-\mathrm{PM}_{2.5}\end{array}$ & $\begin{array}{l}125^{3} \\
125 \\
142^{2}\end{array}$ & $\begin{array}{l}1 \text { in } 3 \\
1 \text { in } 3 \\
1 \text { in } 3\end{array}$ & $\begin{array}{l}\text { SLAMS } \\
\text { SLAMS } \\
\text { SLAMS }\end{array}$ & $\begin{array}{l}\text { Middle } \\
\text { Middle } \\
\text { Neigh. }\end{array}$ & $\begin{array}{l}\mathrm{H}, \mathrm{P}, \mathrm{S} \\
\mathrm{H}, \mathrm{P}, \mathrm{S} \\
\mathrm{H}, \mathrm{P}\end{array}$ \\
\hline
\end{tabular}


Table 3 (Continued)

Existing Montana Ambient Air Monitoring Network

\begin{tabular}{|c|c|c|c|c|c|c|c|}
\hline AQS Number & $\begin{array}{c}\text { Site } \\
\text { City-Name }\end{array}$ & Parameter & Method & Frequency & Type & $\begin{array}{l}\text { Spatial } \\
\text { Scale }\end{array}$ & $\begin{array}{l}\text { Location } \\
\text { Type }^{*}\end{array}$ \\
\hline \multicolumn{8}{|c|}{ 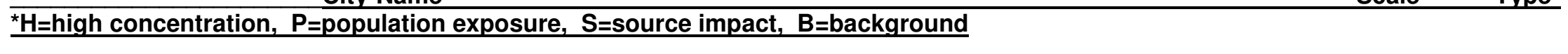 } \\
\hline 30-063-0024 & Missoula-Boyd Park & $\begin{array}{l}81102-\mathrm{PM}_{10} \\
85101-\mathrm{PM}_{10}\end{array}$ & $\begin{array}{l}122^{4} \\
122\end{array}$ & $\begin{array}{l}\text { Continuous } \\
\text { Continuous }\end{array}$ & $\begin{array}{l}\text { SLAMS } \\
\text { SLAMS }\end{array}$ & $\begin{array}{l}\text { Neigh. } \\
\text { Neigh. }\end{array}$ & $\begin{array}{l}\mathrm{H}, \mathrm{P} \\
\mathrm{H}, \mathrm{P}\end{array}$ \\
\hline 30-063-0031 & Missoula-Health Dept. & $\begin{array}{l}81102-\mathrm{PM}_{10} \\
85101-\mathrm{PM}_{10} \\
88101-\mathrm{PM}_{2.5}\end{array}$ & $\begin{array}{l}125^{3} \\
125 \\
142^{2}\end{array}$ & $\begin{array}{l}1 \text { in } 6 \\
1 \text { in } 6 \\
1 \text { in } 3 \\
\text { Collocated }\end{array}$ & $\begin{array}{l}\text { SLAMS } \\
\text { SLAMS } \\
\text { SLAMS }\end{array}$ & $\begin{array}{l}\text { Neigh. } \\
\text { Neigh. } \\
\text { Neigh. }\end{array}$ & $\begin{array}{l}\mathrm{H}, \mathrm{P} \\
\mathrm{H}, \mathrm{P} \\
\mathrm{H}, \mathrm{P}\end{array}$ \\
\hline & & $\mathrm{PM}_{2.5}$ Speciation & $810^{6}$ & 1 in 3 & $\begin{array}{l}\text { Trends } \\
\text { Speciation }\end{array}$ & Neigh. & $\mathrm{H}, \mathrm{P}$ \\
\hline 30-081-0007 & Hamilton-Parking Spot \#46 & $\begin{array}{l}88101-\mathrm{PM}_{2.5} \\
88502-\mathrm{PM}_{2.5}\end{array}$ & $\begin{array}{l}142^{2} \\
170^{8}\end{array}$ & $\begin{array}{l}1 \text { in } 3 \\
\text { Continuous }\end{array}$ & $\begin{array}{l}\text { SLAMS } \\
\text { SPM }\end{array}$ & $\begin{array}{l}\text { Neigh. } \\
\text { Neigh. }\end{array}$ & $\begin{array}{l}\mathrm{H}, \mathrm{P} \\
\mathrm{H}, \mathrm{P}\end{array}$ \\
\hline 30-089-0007 & Thompson Falls-High School & $\begin{array}{l}81102-\mathrm{PM}_{10} \\
85101-\mathrm{PM}_{10} \\
88101-\mathrm{PM}_{2.5}\end{array}$ & $\begin{array}{l}125^{3} \\
125 \\
142^{2}\end{array}$ & $\begin{array}{l}1 \text { in } 6 \\
1 \text { in } 6 \\
1 \text { in } 3\end{array}$ & $\begin{array}{l}\text { SLAMS } \\
\text { SLAMS } \\
\text { SLAMS }\end{array}$ & $\begin{array}{l}\text { Neigh. } \\
\text { Neigh. } \\
\text { Neigh. }\end{array}$ & $\begin{array}{l}\mathrm{H}, \mathrm{P} \\
\mathrm{H}, \mathrm{P} \\
\mathrm{H}, \mathrm{P}\end{array}$ \\
\hline 30-093-0005 & Butte-Greeley School & $\begin{array}{l}81102-\mathrm{PM}_{10} \\
85101-\mathrm{PM}_{10} \\
88101-\mathrm{PM}_{2.5}\end{array}$ & $\begin{array}{l}122^{4} \\
122 \\
142^{2}\end{array}$ & $\begin{array}{l}\text { Continuous } \\
\text { Continuous } \\
1 \text { in } 3\end{array}$ & $\begin{array}{l}\text { SLAMS } \\
\text { SLAMS } \\
\text { SLAMS }\end{array}$ & $\begin{array}{l}\text { Neigh. } \\
\text { Neigh. } \\
\text { Neigh. }\end{array}$ & $\begin{array}{l}\mathrm{H}, \mathrm{P}, \mathrm{S} \\
\mathrm{H}, \mathrm{P}, \mathrm{S} \\
\mathrm{H}, \mathrm{P}\end{array}$ \\
\hline
\end{tabular}


Table 3 (Continued)

Existing Montana Ambient Air Monitoring Network

\begin{tabular}{|c|c|c|c|c|c|c|c|}
\hline AQS Number & $\begin{array}{c}\text { Site } \\
\text { City-Name } \\
\end{array}$ & Parameter & Method & Frequency & Type & $\begin{array}{l}\text { Spatial } \\
\text { Scale }\end{array}$ & $\begin{array}{r}\text { Location } \\
\text { Type }^{*}\end{array}$ \\
\hline \multicolumn{8}{|c|}{${ }^{*} \mathrm{H}=$ high concentration, $\mathrm{P}=$ population exposure, $\mathrm{S}=$ source impact, $\mathrm{B}=$ =background } \\
\hline 30-093-0009 & Butte-Front Street & $88502-\mathrm{PM}_{2.5}$ & $731^{5}$ & Continuous & SPM & Neigh. & $\mathrm{H}, \mathrm{P}$ \\
\hline $30-111-0066$ & Billings-Coburn Road & $42401-\mathrm{SO}_{2}$ & $100^{7}$ & Continuous & SLAMS & Neigh. & $\mathrm{H}, \mathrm{S}$ \\
\hline $30-111-0085$ & Billings-St. Luke's & $\begin{array}{l}42101-\mathrm{CO} \\
88502-\mathrm{PM}_{2.5}\end{array}$ & $\begin{array}{l}093^{1} \\
731^{5}\end{array}$ & $\begin{array}{l}\text { Continuous } \\
\text { Continuous }\end{array}$ & $\begin{array}{l}\text { SLAMS } \\
\text { SPM }\end{array}$ & $\begin{array}{l}\text { Micro. } \\
\text { Micro. }\end{array}$ & $\begin{array}{l}\mathrm{H}, \mathrm{P}, \mathrm{S} \\
\mathrm{P}\end{array}$ \\
\hline $30-111-1065$ & Billings-Lockwood Park & $88101-\mathrm{PM}_{2.5}$ & $142^{2}$ & 1 in 3 & SLAMS & Neigh. & $\mathrm{H}, \mathrm{P}$ \\
\hline
\end{tabular}


Table 4

Montana Monitoring Site Locations

\begin{tabular}{|c|c|c|c|c|c|}
\hline AQS Number & Site Name & Address & MSA/Code & Latitude & Longitude \\
\hline $30-013-0001$ & Overlook Park & $\begin{array}{l}10^{\text {th }} \text { Ave.S. and } 2^{\text {nd }} \text { St. E. } \\
\text { Great Falls }\end{array}$ & Great Falls/24500 & 47.49417 & -111.30278 \\
\hline 30-013-1026 & High School & $\begin{array}{l}3^{\text {rd }} \text { Ave. S. and } 17^{\text {th }} \text { St. E. } \\
\text { Great Falls }\end{array}$ & Great Falls/24500 & 47.20222 & -111.27889 \\
\hline $30-029-0007$ & Ball Park & $\begin{array}{l}\text { C St. and } 4^{\text {th }} \text { Ave. E N } \\
\text { Columbia Falls }\end{array}$ & & 48.38111 & -114.17472 \\
\hline $30-029-0009$ & Dead End & $\begin{array}{l}\text { End of } 10^{\text {th }} \text { St. } \\
\text { Whitefish }\end{array}$ & & 48.39972 & -114.33361 \\
\hline $30-029-0010$ & Moose's Saloon & $\begin{array}{l}\text { Idaho Ave. } \\
\text { Kalispell }\end{array}$ & & 48.20229 & -114.31349 \\
\hline $30-029-0047$ & $\begin{array}{l}\text { Flathead } \\
\text { Electric }\end{array}$ & $\begin{array}{l}\text { Center St. and Woodland } \\
\text { Ave. } \\
\text { Kalispell }\end{array}$ & & 48.2025 & -114.30556 \\
\hline $30-031-0006$ & $\begin{array}{l}\text { Wastewater } \\
\text { Treatment Plant }\end{array}$ & $\begin{array}{l}2545 \text { Springhill Rd. } \\
\text { Bozeman }\end{array}$ & & 45.72631 & -111.0673 \\
\hline 30-013-0008 & ConAgra & $\begin{array}{l}100 \text { S. Broadway } \\
\text { Belgrade }\end{array}$ & & 45.77277 & -111.1775 \\
\hline $30-013-0013$ & Park Entrance & $\begin{array}{l}\text { West Entrance to } \\
\text { Yellowstone National Park }\end{array}$ & & 44.65777 & -11109083 \\
\hline $30-013-0016$ & City Center & West Yellowstone & & 44.6617 & -111.1049 \\
\hline
\end{tabular}


Table 4 (Continued)

Montana Monitoring Site Locations

\begin{tabular}{|c|c|c|c|c|c|}
\hline AQS Number & Site Name & Address & MSA/Urbanized Area & Latitude & Longitude \\
\hline 30-049-0018 & Lincoln School & $\begin{array}{l}1325 \text { Poplar St. } \\
\text { Helena }\end{array}$ & & 46.60388 & -112.03527 \\
\hline 30-049-0026 & $\begin{array}{l}\text { Rossiter Pump } \\
\text { House }\end{array}$ & $\begin{array}{l}1497 \text { Sierra Rd. East } \\
\text { Helena }\end{array}$ & & 46.6588 & -112.0123 \\
\hline 30-053-0018 & $\begin{array}{l}\text { Courthouse } \\
\text { Annex }\end{array}$ & $\begin{array}{l}418 \text { Mineral Ave. } \\
\text { Libby }\end{array}$ & & 48.38416 & -115.54805 \\
\hline 30-063-0005 & $\begin{array}{l}\text { Malfunction } \\
\text { Junction }\end{array}$ & $\begin{array}{l}\text { Fairgrounds } \\
\text { Missoula }\end{array}$ & Missoula/33540 & 46.84889 & -114.01611 \\
\hline 30-063-0021 & Seeley Lake & Seeley Lake & Missoula/33540 & 47.1771 & -113.4827 \\
\hline 30-063-0024 & Boyd Park & $\begin{array}{l}3100 \text { Washburn Rd. } \\
\text { Missoula }\end{array}$ & Missoula/33540 & 46.84222 & -114.01972 \\
\hline 30-063-0031 & Health Dept. & $\begin{array}{l}301 \text { West Alder } \\
\text { Missoula }\end{array}$ & Missoula/33540 & 46.87491 & -113.99525 \\
\hline 30-081-0007 & $\begin{array}{l}\text { Parking Spot } \\
\# 46\end{array}$ & $\begin{array}{l}\text { Madison and } 3^{\text {rd }} \text { St. S. } \\
\text { Hamilton }\end{array}$ & & 46.24563 & -114.15886 \\
\hline 30-089-0007 & High School & $\begin{array}{l}\text { Golf and Haley } \\
\text { Thompson Falls }\end{array}$ & & 47.59639 & -115.32361 \\
\hline 30-093-0005 & Greeley School & Butte & & 46.0027 & -112.5004 \\
\hline 30-093-0009 & Front Street & Butte & & 45.9988 & -112.5366 \\
\hline
\end{tabular}


Table 4 (Continued)

Montana Monitoring Site Locations

\begin{tabular}{|c|c|c|c|c|c|}
\hline AQS Number & Site Name & Address & MSA/Urbanized Area & Latitude & Longitude \\
\hline $30-111-0066$ & Coburn Road & $\begin{array}{l}\text { Coburn Hill Rd. } \\
\text { Billings }\end{array}$ & Billings/13740 & 45.78667 & -108.45778 \\
\hline 30-111-0085 & Saint Luke's & $\begin{array}{l}2^{\text {nd }} \text { Ave. N. and N. } 32^{\text {nd }} \text { St. } \\
\text { Billings }\end{array}$ & Billings/13740 & 45.78218 & -108.51153 \\
\hline 30-111-1065 & Lockwood Park & $\begin{array}{l}\text { Old Hardin Road } \\
\text { Lockwood }\end{array}$ & Billings/13740 & 45.80194 & -108.42611 \\
\hline
\end{tabular}

